\title{
2D Electrical Resistivity Imaging of Bedrock Fissures in Ogbomoso, Southwestern Nigeria
}

\author{
* Akinlabi I. A. and Bayowa O. G.
}

Department of Earth Sciences, Ladoke Akintola University of Technology, P.M.B 4000, Ogbomoso, Nigeria.

* Corresponding Author: iaakinlabi@lautech.edu.ng.

$+2347060592144$

Submitted on: 02/08/2021 Accepted on: 25/09/2021

\begin{abstract}
$2 D$ electrical resistivity surveys were conducted around the site of the failed proposed Ogbomoso North Secretariat building with a view to examining the trend of suspected bedrock fissures and assessing the vulnerability of structures in the vicinity to potential failure. Electrical Resistivity Tomography data were acquired along ten traverses 80-200 m long each, using the dipole-dipole electrode configuration with station interval of $5 \mathrm{~m}$ and expansion factor, $n$, varied from 1 to 6 . The data were processed by using $2 D$ resistivity inversion technique in the Dippro ${ }^{T M}$ software package to generate $2 D$ resistivity sections beneath the traverses. The 2D resistivity sections delineated 2-19 m thick typically clay overburden underlain by bedrock with resistivity ranging from 103 to 59767 Sm, and anomalously low resistivity zones suspected to be fissures within the bedrock. The bedrock fissures are generally 5-20 m wide and occur at depths ranging from $5 \mathrm{~m}$ to $>25 \mathrm{~m}$ beneath the traverses. The fissures trend southward toward the roundabout and front of the College of Health Sciences premises. The incessant road failures and groundwater seepages observed within the study area are attributable to the network of bedrock fissure.
\end{abstract}

Keywords: 2D resistivity section, dipole-dipole, bedrock fissures, incessant road failures, groundwater seepages

\section{Introduction}

Over the years, there has been steady increase in the application of geophysical techniques to investigate many types of civil engineering-related problems (Kowalczyk et al., 2015; Kowalczyk et al., 2017; Akinlabi and Ayanrinde, 2018; Akinlabi et al., 2018; Skutnik et al., 2018; Trappe and Kneisel, 2019; Lech et al., 2020; Gonclaves et al., 2021). Some of the problems include collapse of buildings and bridges due to distress in their foundation, incessant failure of portions of roads pavement and anomalous seepage through engineering structures. These problems usually arise due to poor engineering design and may be precipitated by subsurface underlying geological structures such as fissures (AZGS, 2015; Conway, 2016). Fissures in bedrock have long been known to undermine the integrity of engineering structures (Li, 2015; Ye, 2015; Wang, 2016). They serve as conduit through which groundwater seeps in bedrock or partly consolidated deposits. Water-logged or marshy areas most times have been discovered to be underlain by fissured bedrock (Bayode and Akpaoarebe, 2011; Onoja and Osifila, 2015; Carreon-Freyre et al., 2016; Mandal and Mishra, 2019). The destructive tendencies of fissures to civil engineering structures, therefore, cannot be overlooked.

The electrical resistivity method has been used to delineate bedrock fissures with huge success in the past because it is cost-effective and time-saving (Obiadi, et al., 2012; Al-Fares and Asfahani, 2018; Olorunfemi, et al., 2020). Sangodiji and Olorunfemi, 2013, carried out geophysical investigation of foundation failure of the distressed former building of Ogbomoso North Local Government Secretariat using Electrical Resistivity (ER) method involving Vertical Electrical Sounding (VES) and Electrical Resistivity Tomography (ERT) techniques. The authors delineated a 20-30 m wide fracture zone trending in the NESW direction around the distressed building. The failure of the building foundation was suspected to have been precipitated by differential settlement within the suspected faulted zone. However, the lateral extent 
and complete orientation of the fault zone could not be ascertained by the study due to insufficient number of traverses established around the area. Hence, there is the need to carry out further study to map the trend of the bedrock fissures and determine the cause of incessant failure of roads pavement and groundwater seepages in the area.

The study area is situated in Ogbomoso North, Southwestern Nigeria and lies within Latitudes $8^{\circ} 9.8^{\prime}-8^{\circ}$ $10.1^{\prime}$ and Longitudes $4^{\circ} 15.4^{\prime}-4^{\circ} 16.1^{\prime}$ (Figure 1). The area is accessible by tarred roads and footpaths. It is located within the tropical climate and characterized by two distinct seasons namely: the wet and the dry seasons. The wet season begins from March and ends in October, with a little break in August, while the dry season begins in November and ends in March (Iwena, 2018). The mean annual temperature is $27^{\circ} \mathrm{C}$ with relative humidity varying from 60 to $80 \%$. The vegetation is the rain forest type consisting of tall, crowned trees mixed with thick undergrowth.

Ogbomoso geology is a member of the Precambrian Basement Complex rocks of Nigeria (Schluter, 2006; Obaje, 2009). The lithological units include quartzite, granite-gneiss and banded gneiss. The quartzite is light coloured and may be part of the migmatite-gneiss-quartzite complex, mainly composed of quartz. The study area is predominantly underlain by granite-gneiss. The rock is medium to coarse-grained, foliated and largely re-crystallized rocks with low quantity of mica and chlorite. The gneisses display compositional banding where the minerals are arranged into bands of more mafic minerals that are developed under a very high pressure and temperature condition (Afolabi et al., 2013).

\section{Material and Methods}

Preliminary studies of the area involved a review of previous works (Sangodiji and Olorunfemi, 2013), acquisition of topographic and geologic maps and resistivity measurements along nine (9) traverses of lengths ranging from 80 to $200 \mathrm{~m}$ with station interval of $5 \mathrm{~m}$ within the study area (Figure 1). Traverse 1 trends NE-SW while Traverses 2-10 trend NW-SE directions. All stations were georeferenced using the Geographic Positioning System (GPS) for accuracy. The 2D electrical resistivity tomography data were acquired with the aid of the ABEM Signal Averaging System (SAS) 4000C, by using the dipole-dipole array. The expansion factor " $n$ " for the data acquisition was varied between 1 and 6 . The data were used to generate $2 \mathrm{D}$ resistivity inverted sections along the traverses by using $2 \mathrm{D}$ inversion technique in Dippro ${ }^{\mathrm{TM}}$ software. The 2D resistivity sections obtained were qualitatively interpreted to reveal the presence of bedrock fissures in the area.

\section{Results and Discussion}

The 2D resistivity sections which reveal the vertical and lateral subsurface resistivity distribution beneath the study area are presented as inverted sections which depict overburden material, typically clay underlain by fresh bedrock. Overburden in this context refers to materials above the fresh bedrock comprising the topsoil, weathered layer and presumably the partly weathered bedrock.

There is apparently is no clear boundary between the topsoil and the weathered layer except beneath Traverse 8 . The bedrock is inundated with weak zones characterized by low resistivity, suspected to be fissures and believed to have been precipitated by intense tectonic activities in the area (Olorunfemi et al., 2020). Detailed description of the 2D resistivity sections obtained beneath the traverses is presented below. 


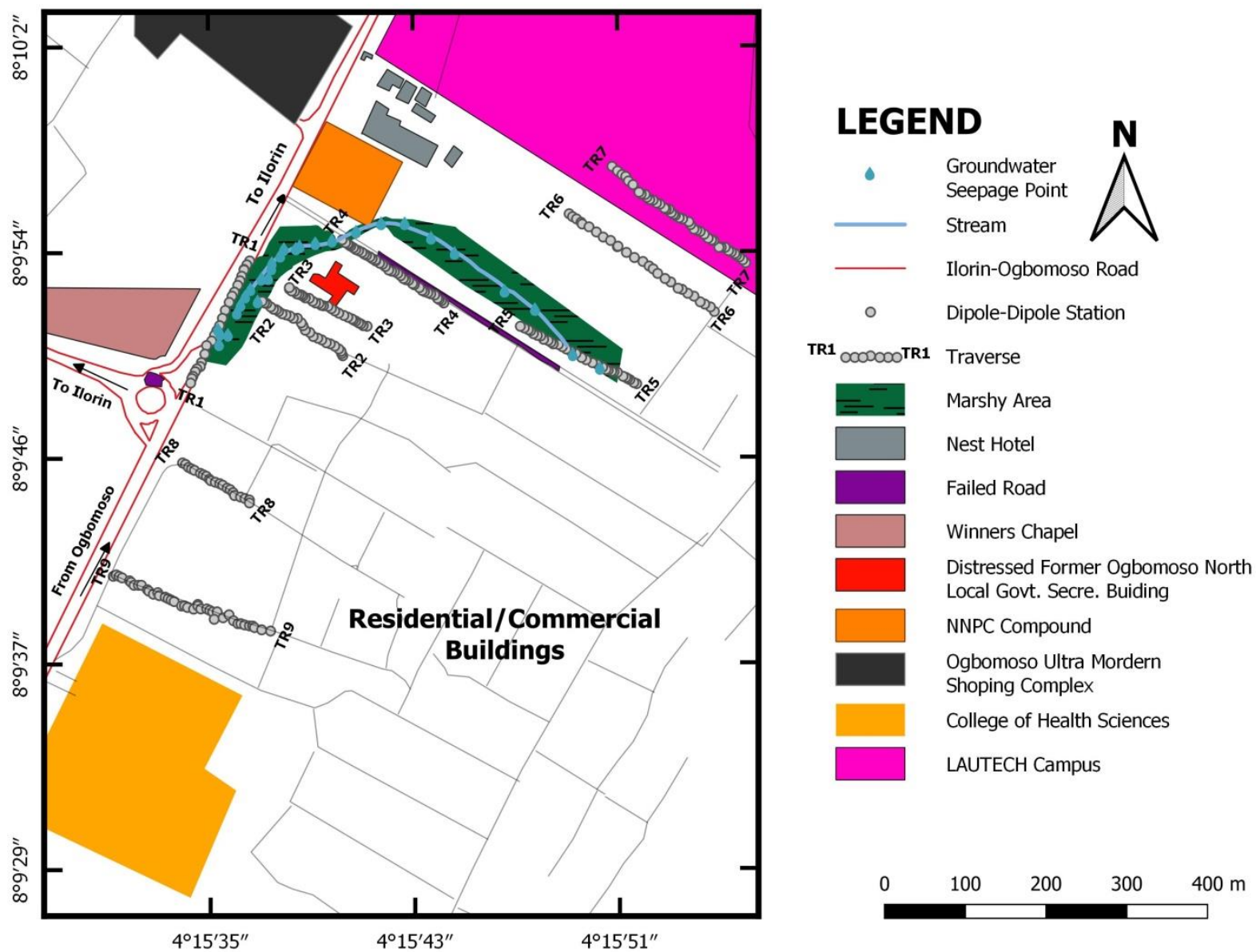

Figure 1: Base map of the study area indicating the traverses

The 2D resistivity sections beneath Traverse 1 (Figure 2) reveals an overburden with resistivity ranging from 2.0 to $89.6 \Omega \mathrm{m}$ and thickness varying from $7-11 \mathrm{~m}$. The resistivity of the fresh bedrock ranges from 279 to $4962 \Omega \mathrm{m}$. The low values represent the bedrock underlying the southwest end of the traverse which appears to be intensely weathered. The low resistivity zones observed at distances 40-60 m and 90-110 m are suspected to be bedrock fissures.

Traverse 2 is underlain by $7-10 \mathrm{~m}$ thick overburden with resistivity less than $100 \Omega \mathrm{m}$ at distance $0-80 \mathrm{~m}$ from the northwest end, and a relatively resistive overburden, about $2.5 \mathrm{~m}$ thick, with resistivity 101-360 $\Omega \mathrm{m}$, from distance $80 \mathrm{~m}$ to the southeast end (Figure 3). The bedrock resistivity ranges from 1040 to 4700 $\Omega \mathrm{m}$ and is apparently fissured at distance $30-40 \mathrm{~m}$ beneath $13 \mathrm{~m}$ depths. The more resistive overburden may have been produced by bedrock fissure suspected to have occurred within the stated intervals (Mandal and Mishra, 2019).

The overburden beneath Traverse 3 has resistivity ranging from 13.7 to $404 \Omega \mathrm{m}$ suggestive of clay-sand mixture in varying ratios, while its thickness 5-10 m thick (Figure 4). Resistivity of the fresh bedrock ranges from 4284 to $419621 \Omega \mathrm{m}$. Weak zone suspected to be bedrock fissure occurs at distances $40-60 \mathrm{~m}$ beneath $10 \mathrm{~m}$ depth. 


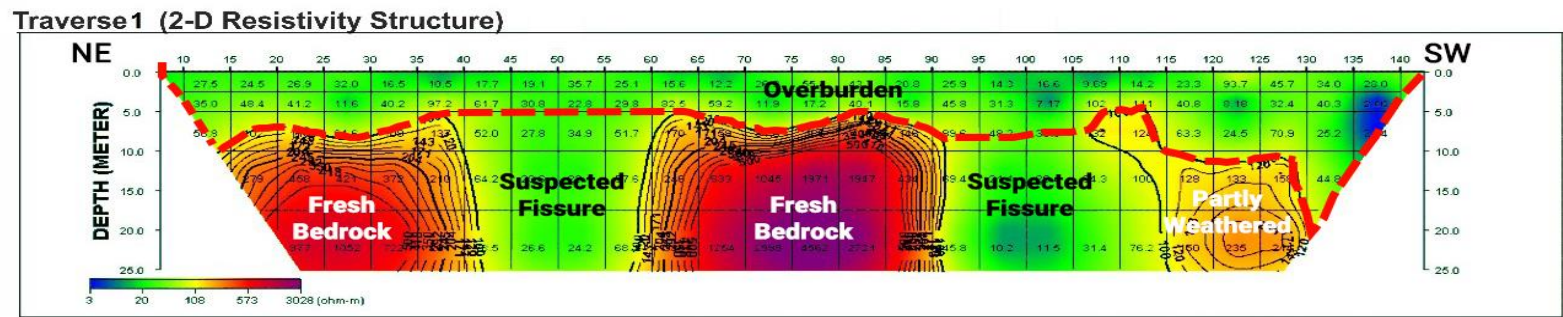

Figure 2: 2D Resistivity section beneath Traverse 1

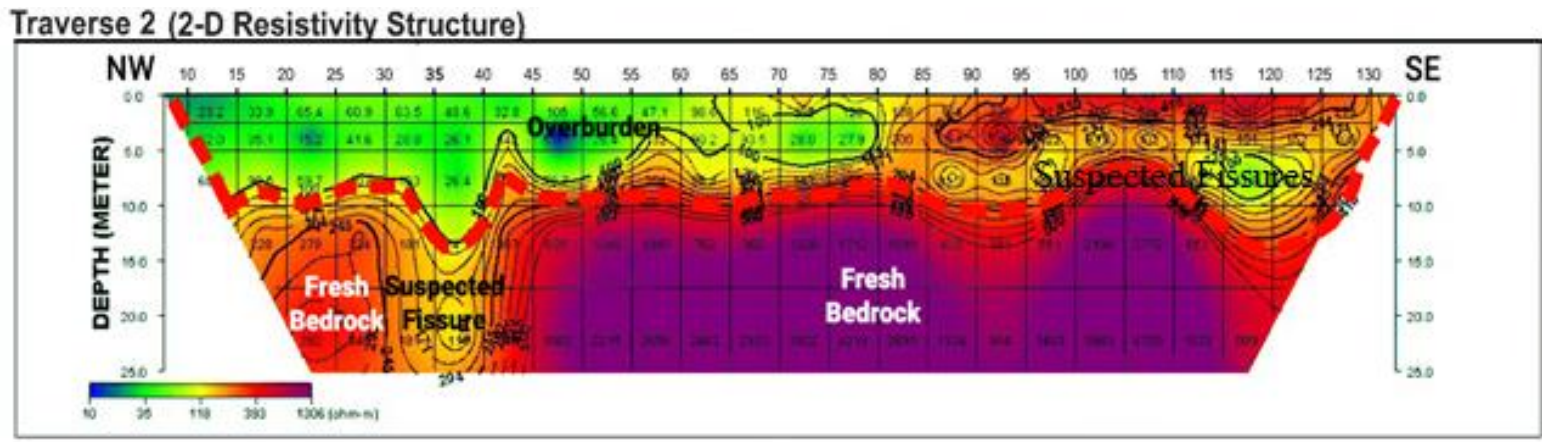

Figure 3: 2D Resistivity section beneath Traverse 2

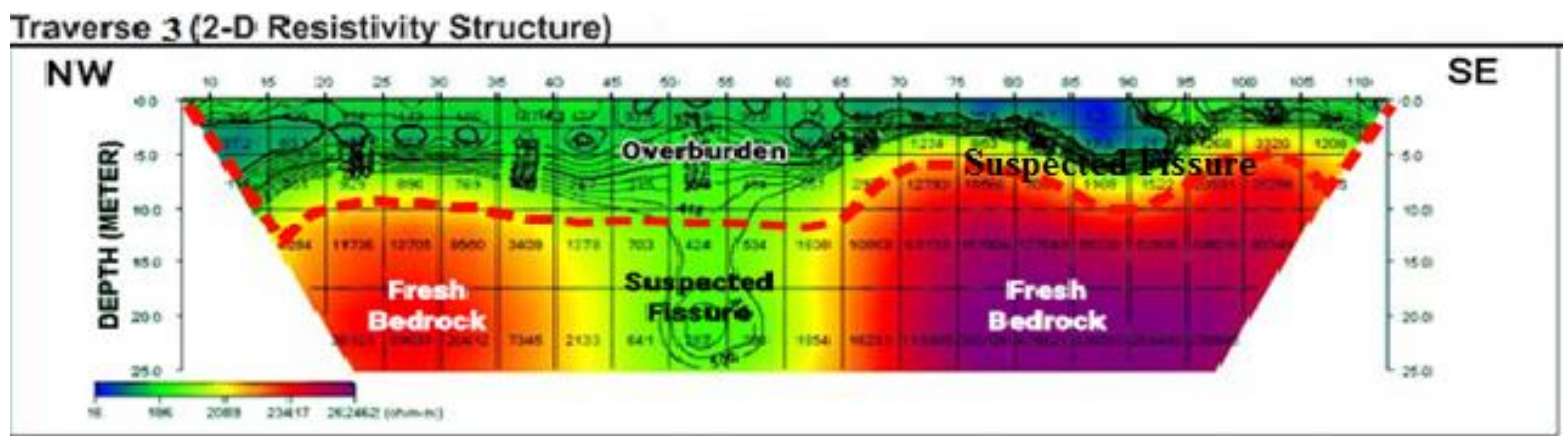

Figure 4: 2D Resistivity section beneath Traverse 3

Traverse 4 is underlain by an overburden with resistivity ranging from 46 to $424 \Omega \mathrm{m}$ and thickness varying from $2.4 \mathrm{~m}$ to $10 \mathrm{~m}$ (Figure 5). Resistivity of the fresh bedrock beneath the traverse shows resistivity values ranges from 951 to $9096 \Omega \mathrm{m}$. The low resistivity zone occurring at distances $65-70 \mathrm{~m}$ and $105-120 \mathrm{~m}$ beneath $11 \mathrm{~m}$ and $2.5 \mathrm{~m}$ depths respectively, are suspected bedrock fissures.

The 2D resistivity section beneath Traverse 5 (Figure 6) reveals an 8-15 m thick overburden comprising sand-clay mixture of resistivity 7-275 $\Omega \mathrm{m}$ overlain by lateritic hardpan of resistivity $1235-4625 \Omega \mathrm{m}$ in the top $2.5 \mathrm{~m}$ from the northwest end to distance $85 \mathrm{~m}$, and underlain by partly weathered bedrock of resistivity $1040-4625 \Omega \mathrm{m}$. Resistivity of the fresh bedrock ranges from 32602 to $84462 \Omega \mathrm{m}$. The anomalously low resistivity zones observable at distances $55-75 \mathrm{~m}$ and $115-135 \mathrm{~m}$ within the bedrock are suspected to be distressed zones occasioned by fissuring. 
LAUTECH Journal of Civil and Environmental Studies

Volume 7, Issue 2; September, 2021

Traverse 4 (2-D Resistivity Structure)

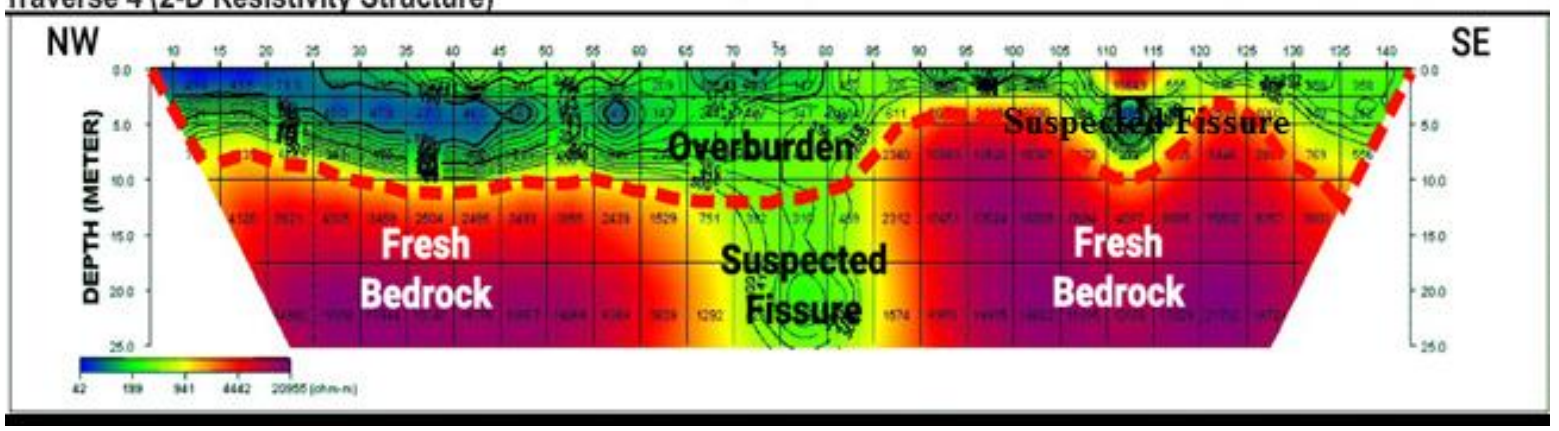

Figure 5: 2D Resistivity section beneath Traverse 4

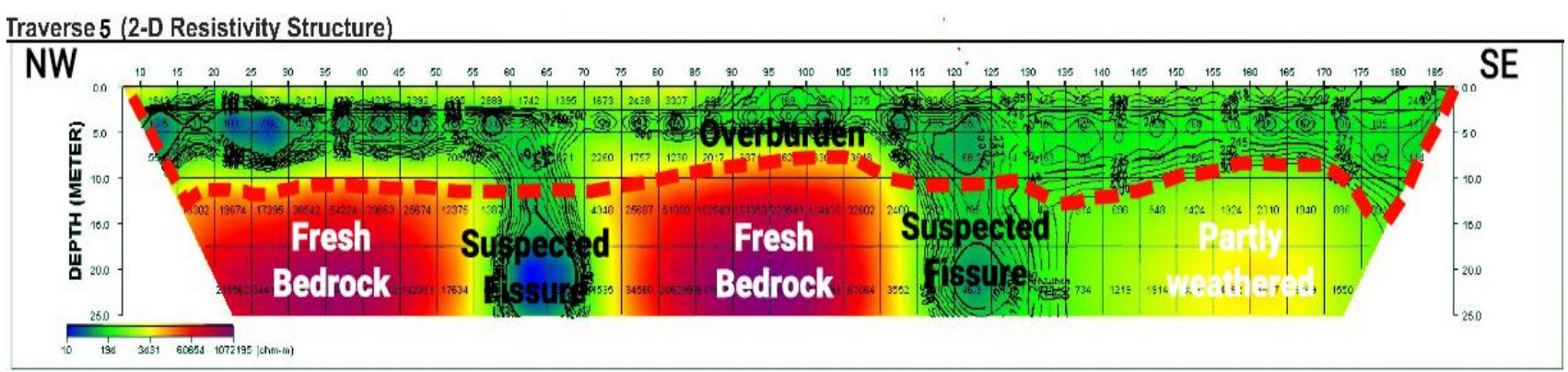

Figure 6: 2D Resistivity section beneath Traverse 5

The 2D resistivity section beneath Traverse 6 (Figure 7), reveals an overburden, 7-19 m thick with resistivity 11-100 $\Omega \mathrm{m}$ typical of clay. Resistivity of the bedrock ranges from 574 to $5244 \Omega \mathrm{m}$. The vertical anomalous low-resistivity zones delineated within distances 40-60 m, 90-110 m and 130-155 m are suspected to be fissures.

The 2D resistivity section beneath Traverse 7 (Figure 8) reveals lateritic topsoil with resistivity 709-2709 $\Omega \mathrm{m}$ and thickness of about $2 \mathrm{~m}$ underlain by weathered layer with resistivity values generally $<100 \Omega \mathrm{m}$ typifying clay with average thickness of about $10 \mathrm{~m}$. The partly weathered bedrock has resistivity varying from 787 to $1414 \Omega \mathrm{m}$. The overburden thickness varies from 3 to $15 \mathrm{~m}$. Resistivity of the fresh bedrock ranges from 2297 to $43076 \Omega \mathrm{m}$. The low-resistivity zones between distances $90-105 \mathrm{~m}$ and $125-140 \mathrm{~m}$ are suspected to be weak zones cutting deep into the basement up to depths beyond $25 \mathrm{~m}$.

Traverse 8 is underlain by lateritic topsoil about 3-5 m thick with resistivity ranging from 267 to $1708 \Omega \mathrm{m}$ (Figure 9) and a weathered layer with resistivity varying from 2 to $95 \Omega \mathrm{m}$ and thickness of about 6 to $11 \mathrm{~m}$. The overburden is about 10-13 m thick. Resistivity of the bedrock ranges from 174 to $337 \Omega \mathrm{m}$ and indicates hydration. The weak zone at distance 40-60 m beneath $13 \mathrm{~m}$ depth is suspected to be bedrock fissure.

The 2D resistivity section beneath Traverse 9, established close to the fence of the College of Health Sciences, Ladoke Akintola University of Technology, Ogbomoso reveals an overburden with resistivity generally less than $100 \Omega \mathrm{m}$ characteristic of clay, and thickness greater than $25 \mathrm{~m}$, beneath lateral distance $75 \mathrm{~m}$ from the northwest end (Fig. 10). It becomes thinner (3-13 m thick) 
2D Electrical Resistivity Imaging of Bedrock Fissures in Ogbomoso, Southwestern Nigeria

Traverse 6 (2-D Resistivity Structure)

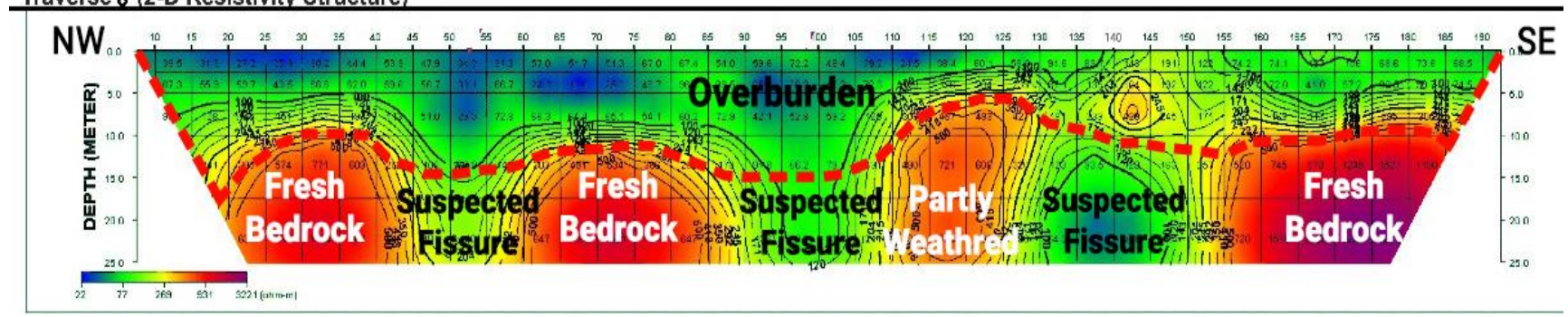

Figure 7: 2D Resistivity section beneath Traverse 6

Traverse 7 (2-D Resistivity Structure)

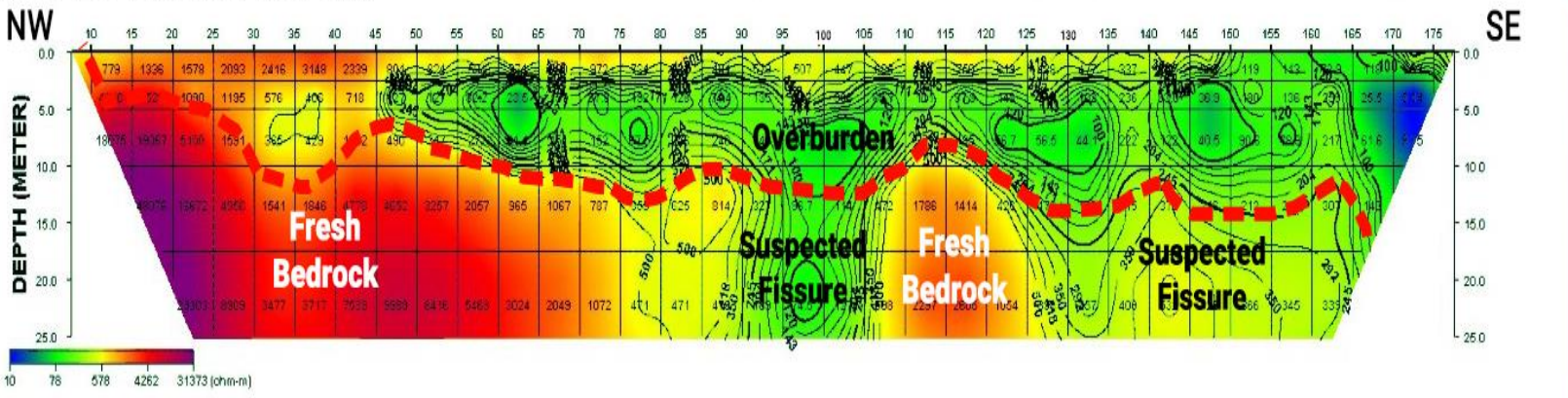

Figure 8: 2D Resistivity section beneath Traverse 7.

TRAVERSE 8 (2-D Resistivity Structure)

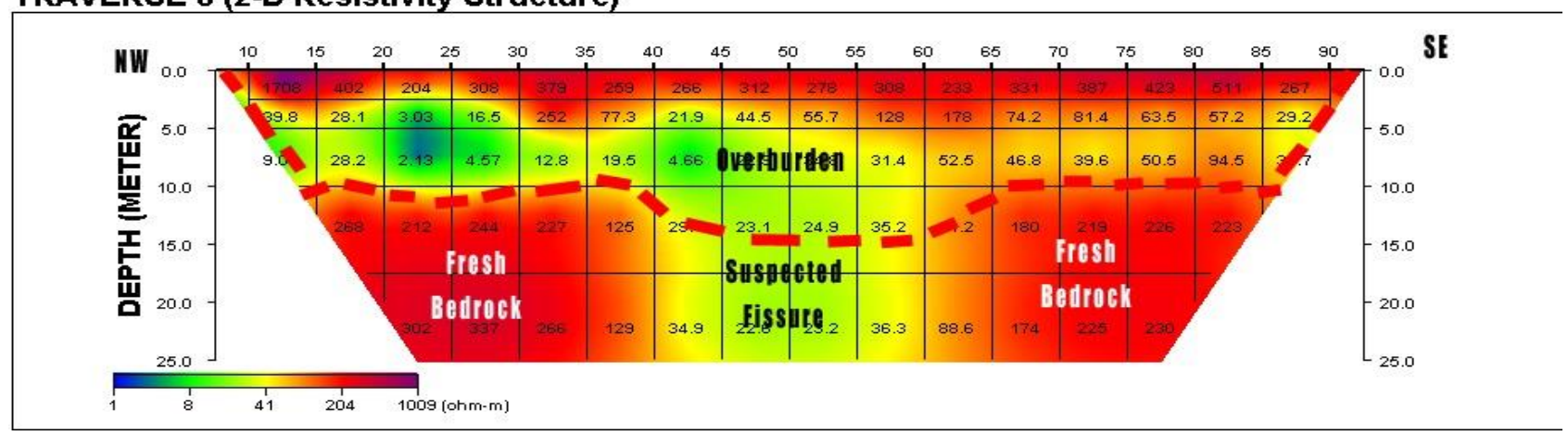

Figure 9: 2D Resistivity section beneath Traverse 8

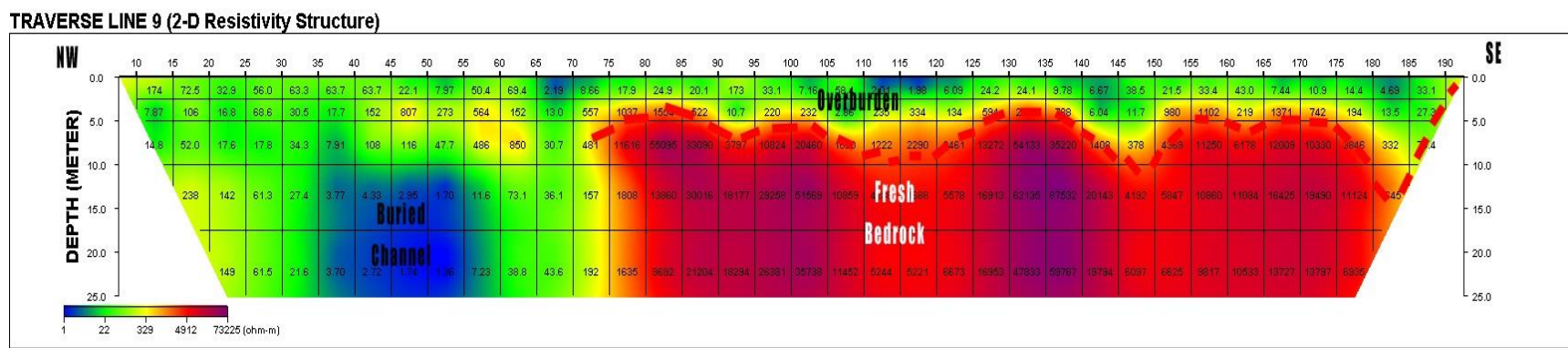

Figure 10: 2D Resistivity section beneath Traverse 9 


\section{LAUTECH Journal of Civil and Environmental Studies}

Volume 7, Issue 2; September, 2021

beneath lateral distance $75-190 \mathrm{~m}$ at the southeast end of the traverse and is underlain by fresh bedrock with resistivity ranging from 3846 to $59767 \Omega \mathrm{m}$. The zone with anomalously low resistivity (less than $10 \Omega \mathrm{m}$ ) observed at distance 35-60 m may have resulted from water saturation due to a suspected buried channel from which groundwater springs onto the road. There is no field evidence that the bedrock fissures have impact on foundations of buildings in the premises of the College of Health Sciences as there are no cracks possibly precipitated by settlement.

Figure 11 presents the plan of the suspected bedrock fissures delineated across the nine traverses established in the study area. The failure of the foundation of the distressed uncompleted former building of Ogbomoso North Local Government Secretariat (now demolished) could have been precipitated by settlement enhanced by the suspected network of bedrock fissures in agreement with the result of Sangodigi and Olorunfemi (2013). In addition, the incessant failure of the road portions and groundwater seepages experienced around the area over time may be attributed to the underlying bedrock fissures (Bayode and Akpaoarebe, 2011; Onoja and Osifila, 2015; Mandal and Mishra, 2019).
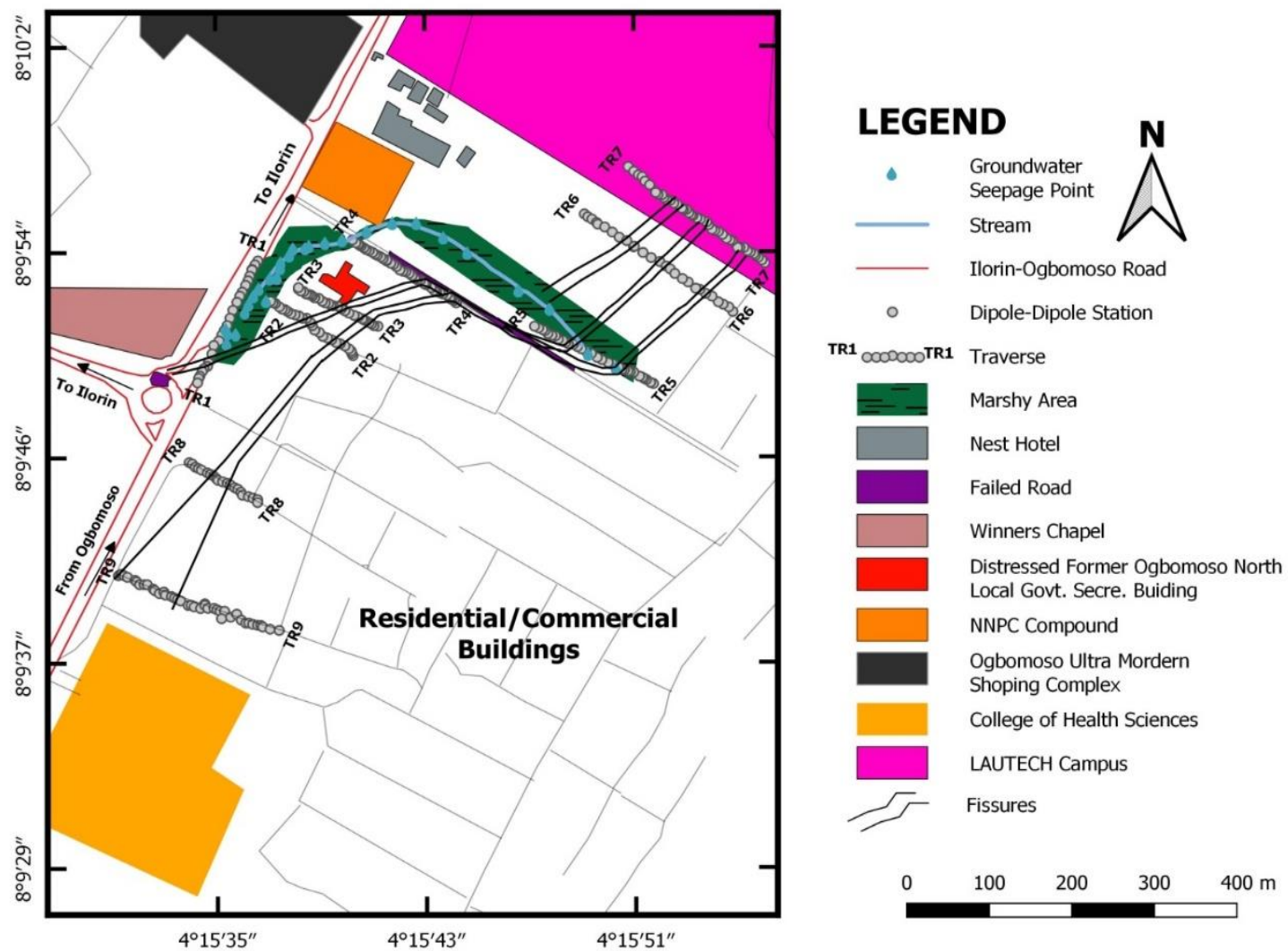

Figure 11: Structural map of the study area indicating the trend of the bedrock fissures

\section{Conclusions}

From the results of the 2D electrical resistivity surveys carried out in this study, it can be concluded that:

(i) The bedrock fissures trend southward and progress toward the roundabout and the premises of the College of Health Sciences.

(ii) The incessant road failures and groundwater seepages observed within the study area are probably attributable to the network of bedrock fissures. 


\section{References}

Afolabi, O.A., Kolawole, L.L., Abimbola, A.F., Olatunji, A.S. and Ajibade, O.M. (2013). Preliminary Study of the Geology and Structural Trends of Lower Proterozoic Basement Rocks in Ogbomoso, SW Nigeria. Journal of Environment and Earth Sciences, 3(8): 82-95.

Akinlabi, I. A. and Ayanrinde, O. S. (2018). Geophysical Investigation of Anomalous Seepage in and around an Earth dam Embankment in Ogbomoso, Southwestern Nigeria. International Journal of Scientific and Engineering Research, 9(7): 1455-1467.

Akinlabi, I. A., Akinrimisi, O. E., Fabunmi, M. A. (2018). Subsurface Investigation of Lanslide using Electrical Resistivity and Self Potential Methods in Oke-Igbo, Southwestern Nigeria. IOSR Journal of Applied Geology and Geophysics, 6(5): 67-74.

Al-Fares, W. and Asfahani, J. (2018). Evaluation of the leakage origin of Abu Baara earthen dam using electrical resistivity tomography, Northwestern Syria. Geofis. Int., 57, 223-237.

AZGS (Arizona Geological Survey) (2015). Locations of mapped earth fissure traces in Arizona (DI-39 v.01.29.2015) Tuzcon, AZ: Arizon Geological Survey Digital Information.

Bayode, S. and Akpaoarebe, O. (2011). An Integrated Geophysical Investigation of a spring in Ibuji, IgbaraOke, Southwestern Nigeria. Ife Journal of Science, 13(1):63-74.

Carreon-Freyre, D., Cerca, M., Ochoa-Gonzalez, G., Teatini, P., Zuniga, F. R. (2016). Shearing along faults and stratigraphic joints controlled by land subsidence and hydraulic gradients in the valley of Queretaro, Mexico. Hydrogeology Journal, 24 (3): 657-674.

Conway, B. D. (2016). Land subsidence and earth fissures in South-Central and Southern Arizona, USA. Hydrogeology Journal, 24 (3), 649-655.

Gonclaves, J. T. D., Botelho, M. A. B., Machado, S. L., Netto, L. G. (2021). Correlation between field electrical resistivity and geotechnical SPT blow counts at tropical soils in Brazil. Environmental Challenges, 5. 1-12.

Iwena, O. A. (2018). Essential Geography for Senior Secondary Schools. Tonad Publishers Limited, Ogun, Nigeria, 583p.

Kowalczyk, S., Zawrzykraj, P., Mieszkowski, R. (2015). Application of electrical resistivity tomography in assessing complex soil conditions. Geol. $Q, 59,367-372$.

Kowalczyk, S., Zawrzykraj, P., Maslakowski, M. (2017). Application of electrical resistivity method in assessing soil for foundation of bridge structures: A case study from the Warsaw environs, Poland. Acta Geodyn. Geomater. 14, 221-234.

Lech, M., Skutnik, Z, Badja, M., Markowska-Lech, K. (2020). Applications of Electrical Resistivity Surveys in Solving Selected Geotechnical and Environmental Problems. Appl. Sci., 10(7), 2263; https://doi.org/10.3390/app10072263.

$\mathrm{Li}, \mathrm{W}$. (2015). Research progress and future work on earth fissures in Su-Xi-Chang area (in Chinese). Earth, 5, p.372-374.

Mandal, A. and Mishra, U. (2019). Integrated Geophysical Investigation to map shallow surface alteration/fracture zones of Atri and Tarabalo hot springs, Odisha, India. Geothermics, 77, 24-33.

Obaje, N.G. (2009). Geology of Mineral Resources in Nigeria. Springer-Verlag BerlinHeidelberg. Germany. p. 1-221. DOI: 10.1007/978-3-540-92685-6.

Obiadi, I. I., Onwuemesi, A. G., Anike, O. L., Obiadi, C. M., Ajaegwu, N. E., Anakwuba, E. K., Akpunonu, E. O., Ezim, E. O. (2012). Imaging subsurface fracture characteristics using 2D Electrical Resistivity Tomography. International Research Journal of Engineering Science, Technology and Innovation, 1(4):103-110.

Olorunfemi, M.O., Oni, A.G., Bamidele, O.E., Fadare, T.K., and Aniko, O. O. (2020). Combined geophysical investigations of the characteristics of a regional fault zone for groundwater development in a basement complex terrain of South-west Nigeria. SN Applied Sciences. 2:1033, https://doi.org/10.1007/s42452-020-2363-6. 


\section{LAUTECH Journal of Civil and Environmental Studies}

Volume 7, Issue 2; September, 2021

Onoja, S. O. and Osifila, O. J. (2015). Integrated Geophysical Investigation of a Suspected Spring in Igbokoran, Ikare-Akoko, Southwestern Nigeria. IOSR Journal of Applied Geology and Geophysics, 3(5), 83-91.

Sangodigi, E.E. and Olorunfemi, M.O. (2013). Geophysical Investigation of a Suspected Foundation Failure at Ogbomoso, Southwestern Nigeria. Pacific Journal of Science and Technology. 14(2):522536.

Schluter, T. (2006). Geological Atlas of Africa. Springer-Verlag, Berlin Heidelberg, Germany. p. 1-272.

Skutnik, Z., Badja, M., Lech, M. (2018). Applications of RCPTU and SCPTU with other Geophysical Test Methods in Geotechnical Practice. Hicks, M., Pisano, F., Peuchen, J., Eds; RC Press; London, UK, 2018.

Trappe, J. and Kneisel, C. (2019). Geophysical and Sedimentological Investigations of Peatlands for the Assessment of Lithology and Subsurface Water Pathways. Geosciences, 9, 118.

Wang, G. Y., You, G., Zhu, J., Li, W. (2016). Earth fissures in Su-Xi-Cgang Region, Jiangsu, China. Surveys in Geophysics, 37 (6), 1095-1116.

Ye, S., Wang, Y., Wu, J., Teatini, P., Yu, J., Gong, X., (2015). Characterization of earth fissures in South Jangu, China. Proceedings of the International Association of Hydrological Sciences, 372, 249-253. 